\title{
THE FRAMEWORK OF MAQĀȘID AL-SHARĪ'AH AND ITS IMPLICATION FOR ISLAMIC FINANCE
}

\author{
Asyraf Wajdi Dusuki and Said Bouheraoua*
}

\begin{abstract}
This article aims at examining the concept of maqāșid al-sharī ah of Islamic jurisprudence in order to appreciate its contribution toward more comprehensive, rational and realistic answers to contemporary financial issues and thereby to increase the awareness of the maqāṣid approach in structuring and developing Islamic finance products. For this purpose, the authors examine the literal and conceptual meaning of maqāṣid al-sharī ah and scrutinise its position in Islamic law. They also highlight the essential elements of maqāșid al-sharī ah and explain how this approach may contribute to better solutions for various Islamic finance issues and challenges.
\end{abstract}

\section{Introduction}

Islamic finance made its first appearance in the 1970s. Since its first inception, Islamic finance has made a phenomenal progress and expanded beyond its traditional markets to become a global phenomenon. The recent global financial crisis has also brought Islamic finance into the limelight. Despite its alleged minimal impact on Islamic finance, the crisis offered an opportunity for it to be introspected and self-evaluated. This is inevitable to determine whether it can become a significant alternative to the conventional system within the global financial market.

Accordingly, Islamic financial institutions must ensure that all of their transactions are shari ${ }^{-} a h$-compliant, not only in their forms and legal technicalities but, more importantly, in their economic substance, which should be premised on the objectives outlined by the sharī'ah, also known as maqāssid al-sharī'ah. Indeed, the Islamic banking system has the potential to become one of the promising sectors for realising the noble objectives of the shari' 'ah, as it resides within a financial trajectory underpinned by the forces of sharī 'ah injunctions. These sharì 'ah injunctions interweave Islamic financial transactions with genuine concern for a just, fair, and transparent society at the same time as prohibiting involvement in illegal activities which are detrimental to social and environmental wellbeing.

* Asyraf Wajdi Dusuki is the Head of Research Affairs, International Shari ${ }^{\prime}$ ah Research Academy for Islamic Finance (ISRA). Said Bouheraoua is a Senior Researcher at ISRA. 
This article aims at examining the concept of maqāșid al-sharī'ah to appreciate its contribution to more comprehensive, rational and realistic answers to various contemporary financial issues. In particular the article suggests a framework based on maqāsid al-sharī 'ah to assist Islamic financial institutions (hereafter IFIs) in making decisions on which courses to pursue and how much to commit to them. The framework may also assist IFIs in managing more effectively and efficiently the ever-emerging conflict of expectations from the part of diverse stakeholders.

The structure of this article is as follows. After delineating the fundamentals of maqāsid al-sharī'ah and the concepts underpinning it, we then focus on the implication of maqāssid al-sharī 'ah for contemporary Islamic finance. This is followed by a more detailed discussion of the 'pyramid of mașlahah' as a framework for managing diverse stakeholder expectations in terms of priorities and responsibilities in Islamic banking operation. A brief conclusion is offered in the final section.

\section{The Fundamentals of Maqāṣid al-Sharī ah}

Prior to any elaboration on the role of maqāșid al-sharī' $a h$ in addressing various Islamic finance challenges, it is pertinent to define maqūșid al-sharī ${ }^{\prime} a h$ and introduce its characteristics and categories. The following sections shall focus specifically on delineating the concept.

\section{Definition of Maqāṣid al-Sharī'ah}

Although Muslim scholars have agreed that the ultimate objective of maqassid al-sharī'ah is to serve the interests (jalb al-mașālih) of all human beings and to save them from harm (daf' al-mafāsid), ${ }^{1}$ they choose to define maqāșid al-sharī ${ }^{\prime} a h$ from a different perspective. Abū Hāamid al-Ghazālī (d. 1111) defined maqāṣid by stressing the $\operatorname{sharī}^{\prime} a h$ 's concern with safeguarding five objectives by stating that:

The very objective of the shari 'ah is to promote the well-being of the people, which lies in safeguarding their faith ( $d \overline{i n}$ ), their lives (nafs), their intellect (' $a q l)$, their posterity (nasl), and their wealth ( $m \bar{a} l)$. Whatever ensures the safeguarding of these five serves public interest and is desirable, and whatever hurts them is against public interest and its removal is desirable. ${ }^{2}$

Al-Shātịibī (d. 1388), in defining maqāṣid al-sharī 'ah, emphasises the epistemological ( 'aqīdah) dimension. According to him:

The primary goal of the shari 'ah is to free man from the grip of his own whims and fancies, so that he may be the servant of Allah by choice, just as he is one without it. ${ }^{3}$

Ibn 'Āshūr (1973), on the other hand, defines maqāṣid from a broader dimension. He stated: 
The all-purpose principle (maqșad 'āmm) of Islamic legislation is to preserve the social order or the community and insure its healthy progress by promoting the well-being and righteousness (șalāh) of the human being. The wellbeing and virtue of human beings consist of the soundness of their intellects and the righteousness of their deeds, as well as the goodness of the things of the world where they live that are put at their disposal. ${ }^{4}$

The uppermost objectives of the shari ' $a$ h rest within the concept of compassion and guidance, ${ }^{5}$ that seeks to establish justice, eliminate prejudice and alleviate hardship. 'Allāl al-Fāsī (d. 1974) stresses these elements in his definition, which states:

The overall objective of Islamic Law is to populate and civilize the earth and preserve the order of peaceful coexistence therein; to ensure the earth's ongoing well-being and usefulness through the piety of those who have been placed there as God's vicegerents; to ensure that people conduct themselves justly, with moral probity and with integrity in thought and action, and that they reform that which needs reform on earth, tap its resources, and plan for the good of all. ${ }^{6}$

By understanding these definitions, it promotes cooperation and mutual supports within the family and society at large. This is manifested in the realisation of mașlahah (public interest) which the Islamic scholars have generally considered to be the all-pervasive value and objective of the shari 'ah and is to all intents and purposes synonymous with compassion. Mașlahah sometimes connotes the same meaning as maqāsid and the scholars have used the two terms almost interchangeably. ${ }^{7}$ To further shed light on our discussion of the objectives of the shari 'ah, especially with regard to their application in the preservation of public interest, the following section elaborates on the principles of maslahah, serving as an important tool to uphold the sharī 'ah.

\section{Principles of Maṣlahah (Consideration of Public Interest)}

Mașlahah ${ }^{8}$ is a juristic device that has always been used in Islamic legal theory to promote public benefit and prevent social evils or corruption. Al-Ghazālī defines maṣlahah as follows:

As for mașlahah, it is essentially an expression for the acquisition of benefit or the repulsion of injury or harm, but that is not what we mean by it, because acquisition of benefits and the repulsion of harm represent human goals, that is, the welfare of humans through the attainment of these goals. What we mean by mașlahah, however, is the preservation of the ends of the shari $a h^{\circ}{ }^{9}$

Here al-Ghazālī reinforces the importance of preservation of the ends of the sharī ah or the objectives of the shari' 'ah (including the protection of faith, life, posterity, 
intellect and wealth) as the fundamental meaning of mașlahah. Following very closely al-Ghazālī's taxonomy, al-Shāțibī, in his book al-Muwāfaqāt, defines mașlaḥah as a principle which concerns the subsistence of human life, the completion of man's livelihood and the acquisition of what his emotional and intellectual qualities require of him, in an absolute sense. Al-Shāțibī has in fact singled out mașlahah as being the only overriding objective of the sharī' $a h$ which is broad enough to comprise all measures that are deemed beneficial to people, including administration of justice and 'ibādah. ${ }^{10}$

\section{Characteristics of Maqāṣid al-Sharī'ah}

Maqāsid al-sharī 'ah has four main characteristics: The first is that they are the basis of legislation, as legislation has to serve the interests of all human beings (jalb al-mașālih) and save them from harm (daf'al-mafāsid). Scholars argued that identification of this characteristic is based on an inductive reading (istiqra ${ }^{\prime}$ ) of the texts of the Qur'ān and the Sunnah. Ibn al-Qayyim (d. 1350) says:

The sharī ah is based on wisdom and achieving people's welfare in this life and in the hereafter. The shari 'ah is all about justice, mercy, wisdom, and good. Thus, any ruling that replaces justice with injustice, mercy with its opposite, common good with mischief, or wisdom with nonsense, is a ruling that does not belong to the shari 'ah even if it is claimed to be so according to some interpretations. ${ }^{11}$

The second characteristic is that maqāșid al-sharī' $a h$ is universal, aiming to serve the interests of mankind and requiring the adherence of all human beings. This is because it is the last revelation, applicable to the whole of mankind everywhere on earth until the end of this world. The supporting evidence is so abundant in the Qur'ān and the Sunnah that it amounts to a thematic recurrence (tawātur ma 'naw $\bar{l}$ ). For example, Allah says, "Now [as for you, O Muhammad,] We have not sent you except to mankind at large" (34:28); "Say [O Muhammad]: 'O mankind, verily, I am an apostle to all of you"” $\left(7: 158^{12}\right)$.

The third characteristic is that maqāșid al-sharī ah is inclusive (absolute). It encompasses all human acts whether they are related to 'ibādah (responsibilities to God) or mu'amalah (responsibilities concerning with other human being). Imām al-Shāfi '̄i (d. 820) stated in his al-Risālah that:

No misfortune will ever descend upon any of the followers of God's religion for which there is no guidance in the book of God to indicate the right way, for God, Blessed and Most High, said: "A Book we have sent down to you that you may bring forth mankind from darkness to light, by the permission of their Lord, to the path of the Almighty, the Praiseworthy" [15:1-2] And He said: And we sent down to you the Book as a clarification for everything and as a guidance and a mercy and good tidings to the Muslims" [16:89]. ${ }^{13}$ 
The fourth characteristic of maqāșid al-sharī'ah is that they are definitive, i.e. it has not been derived from one text or evidence, but from a multiplicity of texts and different aspects of evidences. Clear indications of this characteristic can be found in usūli maxims such as: "Acts are judged by intentions" and "Where there is a definitive text, there is no room for interpretation", as well as in fiqhi maxims such as "[The right to] gain comes with responsibility [for loss]" and "Necessity renders prohibited things permissible".

\section{Categories of Maqāṣid}

The Islamic scholars have generally divided maqāṣid al-sharī 'ah into two main categories: general objectives (maqāṣid 'ämmah) and specific objectives (maqāṣid khāṣsah). Ibn 'Āshūr, in defining general objectives, stated that the general objectives

consist of the deeper meanings ( $m a$ 'ānì) and inner aspects of wisdom (hikam) considered by the Lawgiver (al-shāri ' ) in all the areas and circumstances of legislation (aḥwālal-tashrī ); they are such that they are not confined to a particular type of shari 'ah command. Thus, they include the general characteristics of the sharī $a h$, its all-purpose principles, and any aim contemplated by the legislation. They also include certain meanings and notions that are not present in every sharī ah command but in many of them. ${ }^{14}$

In ușül al-fiqh, on which Islamic jurisprudence is based, scholars such as al-Shāțibī further divide the general objectives or sometimes denote as maṣlaḥah into three sub-categories: al-Shātibī calls these the essentials (darūriyyah), the complementary (hajjiyyah) and the embellishments (tahsininyyah). ${ }^{15}$ The categories are briefly discussed below:

1. Darüriyyah (necessities or essentials) is defined as interests of lives which people essentially depend upon, comprising the five aforementioned objectives of the sharì' $a h$ : religion ( $d \bar{l} n)$; life ( $n a f s)$, intellect ( $a q l$ ), posterity (nasl) and wealth $(m \bar{a} l)$. These are essentials serving as bases for the establishment of welfare in this world and the hereafter. If they are ignored then coherence and order cannot be established and fasād (chaos and disorder) shall prevail in this world, and there will be obvious loss in the hereafter. Some scholars argued that though the five darüriyyāt are essential for human welfare, necessities are not confined to these five maqāșid, hence; they proposed additional darūriyyāt such as equality, freedom and the protection of the environment. ${ }^{16}$

2. Häjiyyah (need or complementary) are interests that supplement the essential interests. It refers to interests whose neglect leads to hardship but not to total disruption of the normal order of life. In other words, these interests, other than the five essentials, are needed in order to alleviate hardship, so that life may be free from distress and predicament. It also acts as provisions that aim 
at removing hardships and/or facilitating life. An example is seen in the sphere of economic transaction where the sharī' $a h$ validated certain contracts such as the salam sale and also that of lease and hire (ijärah) because of the people's need for them, notwithstanding a certain anomaly that is attendant in both. ${ }^{17}$

3. Tahsiniyyah (embellishments). The embellishments refer to interests whose realisation leads to refinement and perfection in the customs and conduct of people at all levels of achievement. For example, the sharī'ah encourages charity to those in need beyond the level of the obligatory zakāh. In customary matters and relations among people, the shari 'ah encourages gentleness, pleasant speech and manner, and fair dealing. Other examples include permission to use beautiful, comfortable things; to eat delicious food; to wear fine clothing and so on. ${ }^{18}$

With regard to the relationship between darūriyyah, hajjiyyah, and tahsiniyyah, al-Shātịīi and other scholars stressed the following:

- Darūriyyah are fundamental to häjiyyah and tahsīniyyah.

- Deficiency in darūriyyah brings deficiency to hăjiyyah and tahsininiyyah in an immutable manner.

- Deficiency in häjiyyah and tahsiniyyah does not necessarily affect darüriyyah.

- An absolute deficiency in hajjiyyah and tahsiniyyah may bring deficiency to some extent in darüriyyah.

- To keep up häjiyyah and tahsiniyyah for the proper maintenance of darüriyyah is desirable.

The second category of maqāssid is the specific objectives of Islamic legislation (al-maqāṣid al-khāsșah), where the area of concern is a specific discipline, such as Islamic transactions or family law or private conduct. Ibn 'Āshūr states that the specific objectives:

consist of the methods (kayfiyyāt) intended by the Lawgiver for realising the useful purposes of human beings or preserving their public interests related to their private conduct. The aim here is to prevent people's pursuit of their personal interests from leading to the undermining of their established public interests, owing to carelessness, whimsical errors, and vain desires. ${ }^{19}$

Notwithstanding the demarcation made by the scholars between general and specific objectives, the two remain inter-related. In fact there is much overlapping and integration between general and specific objectives of the sharì $a h$. Hence, to treat any of the objectives as discrete would be rather naïve. Both categories thereby 
serve as a main framework governing human lives in this world to achieve ultimate happiness in the hereafter.

\section{Maqāṣid al-Sharī ah and Islamic Finance}

The preceding sections have briefly explained the fundamentals and concepts underpinning maqāssid al-shari 'ah. The next focus is to evaluate the implication of maqāșid al-sharī ah for contemporary Islamic finance. As a sharì ah-oriented business entity, the Islamic bank is vigorously expected to be guided by the objectives of the shari ${ }^{-} a h$. There are at least two reasons for establishing the right objectives for any IFI. First, the objectives will be used by the management or policy makers of the IFI in the process of formulating corporate objectives and policies. Secondly, these objectives serve as indicators as to whether the particular IFI is upholding true Islamic principles. Indeed, one of the biggest challenges to IFIs today is to come up with products and services that are shari 'ah-compliant or legitimate from an Islamic viewpoint without undermining the business concerns of being competitive, profitable, and viable in the long run. ${ }^{20}$

Essentially, maqāssid al-sharī' $a h$ in Islamic finance fall in general under the second category of maqāṣid, namely: specific objectives (al-maqāṣid al-khāsșah), as they deal with specific disciplines. However the general objectives are also relevant and directly related as Islamic finance aims at preserving one of the darūriyyāt (necessities) namely: the preservation of wealth (hifz al-māl), which is inter-related with other darüriyyāt, especially the preservation of religion $(d \bar{\imath} n)$. Therefore, it is necessary to examine the objective of wealth preservation as well as general objectives of Islamic finance as a whole.

\section{Preservation of Wealth (Hifz, al-Mäl)}

It is an established fact among Islamic scholars that the preservation of wealth is one of the fundamental and universal principles of the shari 'ah, falling under the darüriyyah category. Naturally, the sharì 'ah whose aim is to preserve and promote the human social order could also have high regards to economic wealth. There are many qur'ānic verses and Prophetic Traditions evidencing that property and wealth have an important status and position in the shari 'ah. In fact Islamic Law introduces many rulings aimed at realising the preservation of wealth in both material and socio-psychological dimensions. Muslim jurists asserted that preservation of wealth is to be achieved through at least five main dimensions. ${ }^{21}$ These dimensions include:

1. Preservation of wealth through the protection of ownership.

2. Preservation of wealth through acquisition and development.

3. Preservation of wealth from damage. 
4. Preservation of wealth through its circulation.

5. Preservation of wealth through its value protection.

Since the above dimensions are integral to the Islamic finance as enshrined by the $\operatorname{sharl~}^{\prime} a h$, the following further elaborates each of the above dimensions.

\section{The Preservation of Wealth through the Protection of Ownership}

The first important dimension for wealth preservation is protection of ownership. Indeed, ownership through exclusive possession has been one of the basic principles of human civilisation that humans would strive to obtain their needs for securing sustenance and safety. Islam therefore recognises the natural desire of mankind to own good things by outlining clear parameters on how to own, use and protect it through balanced and fair legislation. Allah affirms this in the Qur'ān:

Fair in the eyes of men is the love of things they covet: women and sons; heaped-up hoards of gold and silver [...]. (3:14)

Ownership means people's ability in the eyes of the sharī ah to utilise something ( 'ayn) or a benefit (manfa' 'ah) by making use of it directly, by exchanging it, or by giving it freely to someone else, thus excluding all obviated disposition. According to Ibn 'Āshūr, the sharī'ah has identified the following factors as the only means to acquire ownership (tamalluk):

(a) Exclusive possession of something to which no one else has the right, such as cultivating barren land.

(b) Working on a piece of land with its proprietor, such as mughärasah. ${ }^{22}$

(c) Exchanging two counter-values ( ' $i w a d$ ) in such sales, and transferring an item from its owner to someone else, such as donation and inheritance.

Since ownership is recognised in Islam, its protection therefore is inevitable. Allah said: "And do not eat up your property among yourselves for vanities" (Qur'ān $2: 188)$. In order to achieve the purpose of protecting ownership, contracts relating to the various kinds of dealings have been instituted to regulate the transfer of financial rights ( huqūq mäliyyah), whether in exchange of something else or gratis. These contracts have been considered binding because of their formulae, that is, the statements indicating the mutual consent of contracting parties. Certain conditions are required in them for the benefits of both parties. Once a contract has satisfied those conditions, it is valid and produces its legal effect, for the rule is that a contract is binding owing to the existence of its formula. The relevant hadīth corresponding to this is: "Muslims are bound by their conditions, except a condition that makes the lawful unlawful and the unlawful lawful.' ${ }^{23}$ 
It is equally the duty of everyone to respect ownership of one's property, for which reason the sharī 'ah has prescribed compensation for damage to property simply by assessing the damage, regardless whether or not it was intended, for intention has no effect in such situation. ${ }^{24}$ In other words, no property should be taken from its owner without his consent and fair compensation should be given for any utilisation of one's property.

\section{Preservation of Wealth through Acquisition and Development}

Another dimension which is connected to protection of ownership is preservation of wealth through acquisition and development. In fact acquisition and development of wealth have been considered the basis of ownership and property right in Islam and human beings saw that their efforts gave them exclusive right to whatever they could possess as a result. Thus, the Prophet is reported to have said: "If anyone revives a dead land, it belongs to him, and the unjust root has no rights." 25

Furthermore, the scholars argued that if wealth preservation is a higher objective of Islamic law, then its acquisition should take precedence over its preservation. There are many qur'ānic verses and ahādìth which certify this, such as "And when the prayer is finished, then you may disperse through the land and seek of the bounty of Allah [...]" (Qur'ān 62:10). The Prophet, with regard to the essence of this meaning, said: "How fine is rightly acquired wealth in the possession of an upright man" (Ahmad b. Hanbal, Musnad). He also said: "There is no Muslim who plants a seedling or sows a crop, and then an animal or person eats from it, except that it is (recorded) for him as a charity" (al-Bukhārī, Șaḥihh).

Another related aspect of acquisition is development. In fact development and augmentation are connected to asset acquisition. This is particularly true especially if one understands the philosophy behind the imposition of zakāh on economic property, which is also the third pillar of Islam. The requirement for Muslims to pay zakāh implies the need to develop wealth, for example through investment ensuring an asset to continuously grow and not to deplete. A hadith that corresponds to this: "Verily, whoever has charge over an orphan with wealth then let him invest it. He should not leave it to be consumed by zakāh" (al-Dāraquṭn̄ and al-Bayhaqī).

\section{Preservation of Wealth from Damage}

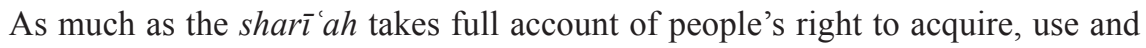
enjoy their property and the corresponding benefits, it also emphasises the need to preserve the property from being damaged and exposed to any form of harm. The preservation of wealth from damage can be looked at from two dimensions: protecting wealth from risk which can cause harm to it; and preventing wealth from damage through its harmful purposes. That is why rules governing the validity 
and validation of contracts and the fulfilment of stipulations have been profoundly instituted in Islamic law. ${ }^{26}$

The concept of protection of wealth and property from risk can be seen in the Qur'ān; for instance, the longest verse in the Qur'ān - 2:282 - clearly directs Muslims to record debts and business dealings and to take witnesses. This prevents the possibility of a party denying what took place, which could lead to a loss of capital. If the dealing takes place during a journey, Allah allows collateral to be taken for the debt, if no record is taken. Such actions are suggested by Allah so that the debtor or business person will become aware and responsible in fulfilling their respective obligations. It is therefore understood that trust of the other party is not sufficient, but steps must be taken to avoid fraudulence and unreasonable losses. This concept is further strengthened by another clear command of Allah: "Spend in the cause of Allah; do not contribute to your destruction with your own hands, but do good, for Allah loves those who do good" (2:195).

In the all the above verses, Allah directed humans not to expose their wealth to the danger of destruction. Such a situation can also occur in business and investment matters, whereby a major risk, if not managed properly, can bring about catastrophic damages that may paralyse a nation's economy and disrupt the lives of the general public. Therefore, handling a danger or risk efficiently is important for avoiding harm and for the sake of the society. The qur'ānic verses above make it clear that risk management is important and that strategic actions must be taken to handle risk efficiently and promptly.

\section{The Preservation of Wealth through its Circulation (rawäj)}

Facilitating the circulation of wealth constitutes an important objective of the sharì' $a h$. In the sharì 'ah, circulation here means the transfer of wealth in the community among as many hands as possible without causing any harm to those who have acquired it lawfully. ${ }^{27}$ The Qur'ān has clearly indicated the need to prevent wealth from remaining in the hands of one person or just moving from one specific person to another:

Whatever [spoils taken] from the people of those villages God has turned over to His Apostle - [all of it] belongs to God and the Apostle, the near of kin [of deceased believers], the orphans, the needy, and the wayfarer, so that it may not be [a benefit] going round and round among such of you as may [already] be rich. (59:7)

This is also found in the hadith of the Prophet in which he stated: "Whoever monopolises a commodity with the intention of overcharging Muslims is a wrongdoer" (Ahmad b. Hanbal, Musnad).

Indeed, circulation of wealth is a very important element of wealth preservation in Islamic law. It guarantees a balanced and harmonious society and sustainable 
economic development. In order to achieve this, the sharī $a h$ establishes a formula that balances between personal natural desire for ownership and fair access of the whole society to a reasonable portion of wealth. This formula can be looked at on two levels: during the life of its owner and after the owner's death. ${ }^{28}$ The measures include:

- Prescribing financial measures, such as zakāh, zakāt al-fiț, kaffārah, to maintain a balanced society and provide a continuous source of income for its lower class.

- Promoting and rewarding charitable acts such as waqf, hibah, hadiyyah, wașiyyah etc. to ensure a healthy circulation of wealth.

- Shifting lending to voluntary sectors, as an act of charity rather than for business.

- Promoting investments and prohibiting hoarding of wealth.

- Prohibiting all types of manipulations or monopolisation that channel wealth to a small segment of wealthy people at the expense of the majority.

Another important means of circulation of wealth is facilitating transactions as much as possible by highlighting their benefits over the minor harm that they might cause. For this reason, the $\operatorname{shari~}^{-} a h$ does not require for the validity of sale contracts that the two counter-values ( iwadayn) be available at the same time, such as in the case of deferred payment sale for which the price as a counter-value to the goods may be postponed to be paid at a certain point in future.

\section{The Preservation of Wealth through its Value Protection}

The emphasis on wealth circulation entails the requirement to protect and preserve its value. Indeed Islamic law put high concerns with the preservation of wealth by protecting its value and natural movement of commodity pricing. Allah affirms this in the Qur'ān: "And do not withhold from the people the things that are their due" (7:85).

In the verse, the word bakhs has a literal meaning of undervaluing or deceiving or trickery in adding to or reducing from the measurement. As a case in point Islam considers money as a medium of measurement rather than a commodity. Hence specific ruling is prescribed upon money transaction as widely discussed by Muslim jurists under kitāb as-sarf, which denotes exchange of gold and silver (currency exchange). On the other hand commodity exchange is governed under different rules and regulation as discussed in Islamic jurisprudence under the topic of kitāb al-buy $\bar{u}$, which denotes exchange of commodity.

The following hadith perhaps explains best the importance of preservation of wealth through its value protection: 
The Prophet appointed a man as governor of Khaybar, who [later] presented him with an excellent type of dates (janib). The Prophet asked, "Are all the dates of Khaybar like this?" He replied, "[No, but] we barter one șā'29 of this (excellent type) for two șā of ours, or two șā of it for three of ours." Allah's Apostle said, "Do not do that (as it is a kind of usury); rather, sell the mixed dates (of inferior quality) for money, and then buy the excellent dates with that money. ${ }^{30}$

In the above hadìth, the Prophet impliedly indicated the need to allow market force to determine the actual value of the dates. This would ensure fair determination of the commodity's price which might be a subject of manipulation and deception due to information asymmetry.

Moreover, the issue of value protection also entails the prohibition of any form of devaluing or overpricing of commodity. Thus, the Prophet prohibited people from buying goods from caravans before they reach the market (talaqqi al-rukbān) and also prohibited najash, which means bidding without real intent of purchase, simply to increase the price.

\section{The Application of Maqāṣid al-Sharī ah in Islamic Finance}

Given the prime importance of the $\operatorname{shar}^{\prime}$ ' $a h$ in Islamic finance, the Islamic financial institution therefore assumes a more vital role than its conventional counterpart. The understanding of the maqāssid al-sharī'ah requires IFIs to submit to the sharī ah by committing them to every contractual obligation and leading their operation in accordance with high virtue and moral consciousness as stipulated by the shari ${ }^{\prime} a h$. For example, while an individual's rights in acquiring properties (property rights) are protected, these rights are governed by rules and ethical codes designed to protect the rights of society. ${ }^{31}$ As such, an Islamic financial institution is not expected to conduct its economic, social and other worldly activities as a self-centred utility maximiser economic agent, as idealised in neoclassical economics; rather the firm is expected to balance between the rights and responsibilities of the individual and those of society. ${ }^{32}$

Essentially, the philosophy of the Islamic financial institution can be fully understood in the context of the overall objectives of the Islamic economic system as enshrined in the maqāșid al-sharī 'ah. ${ }^{33}$ Many prominent Islamic economists, like Chapra, Ahmad, Siddiqui, and Naqvi, have asserted that Islamic banking is a subset of the overall Islamic economic system that strives for a just, fair and balanced society as envisioned and deeply inscribed in maqāsid al-sharī 'ah. Accordingly, the many prohibitions (e.g. interest, gambling, excessive risks, etc.) are to provide a level playing field to protect the interests and benefits of all parties involved in market transactions and to promote social harmony. ${ }^{34}$ 
It is now commonly acknowledged that the consequences of lack of ethics and low morality are not only financial, but also social, environmental and essentially human damages. The recent financial crisis attested the fact that deceit and infectious greed corrupted the financial markets. Consequently, the crisis has brought IFI into the limelight as a possible and viable alternative. The crisis had a limited impact on Islamic finance, although it did not emerge totally unscathed. Nevertheless IFI faces considerable challenges in responding to the various expectations which will determine whether it becomes a significant alternative to its conventional counterpart. IFI should therefore leverage on its robust foundation and underlying principles, deeply rooted in the teachings of the $\operatorname{shari}^{-}$' $a$ h and as enshrined by its higher objectives or maqāṣid al-sharī'ah.

Essentially, the principles of maqāṣid al-sharī ah and mașlahah (protection of public interests) by implication reflect how Islam stresses the importance of taking into account public interests rather than merely individual interests. It also provides a framework for decision making and a mechanism for adapting to change, especially for Islamic financial institutions that are supposed to commit to sharī ah principles. Perhaps the principles of maqāṣid and mașālih can further contribute in delineating the role of IFI in terms of their responsibilities. They offer guidelines for moral judgement on the part of managers and other stakeholders, particularly in solving conflicts that may arise when pursuing various financial and operational issues.

\section{The 'Pyramid of Mașlahah'}

To shed light on our discussion of the application of the principles of maqāsid and mașlahah, this article depicts the principles of mașlahah in a pyramid form, illustrated in Figure 1.

The pyramid of mașlahah functions as a framework and general guideline to an ethical filter mechanism by providing three levels of judgements to be used by managers to resolve ethical conflicts which inadvertently emerge while engaging in various financial programmes and initiatives. ${ }^{35}$ The three levels also reflect the different degrees of importance in terms of fulfilment of responsibility. The bottom level, which is represented by the essentials (darüriyyah), constitutes the most fundamental responsibility to be fulfilled as compared to the other two categories, namely the complementary (hajjiyyah) and the embellishments (tahsiniyyah).

Therefore, as the pyramid moves upwards, the degree of decision making will be less fundamental, albeit more virtuous, so as to attain the perfection and well-being of society. ${ }^{36}$ According to Islamic scholars, the existence of the complementary (hajjiyyah) and the embellishments (tahsiniyyah) depends upon the primary purposes underlying the essentials (protecting and preserving the five objectives of the shari 'ah - faith, life, intellect, posterity, and wealth). The two categories are structurally subservient and substantively complementary to the darūriyyah, to the 


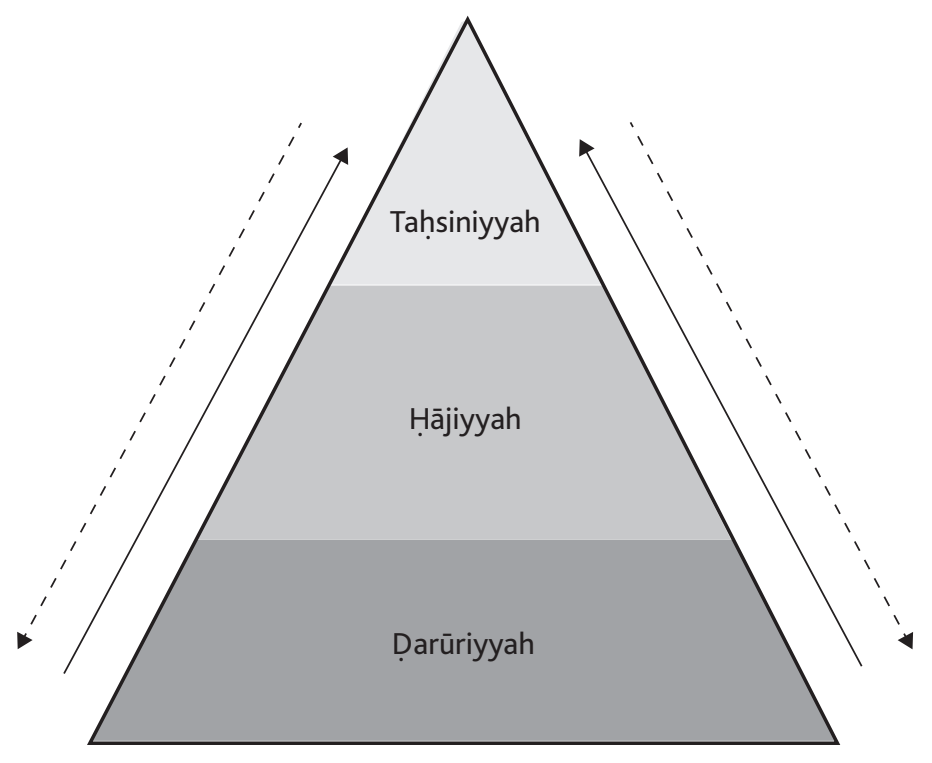

Figure 1 The 'Pyramid of Maṣlaḥah'

extent that any violation affecting the latter produces far-reaching consequences. On the other hand, any damage affecting tahsiniyyah or häjiyyah will result in only minor disturbance in the darüriyyah. Hence, it is essential to preserve the three categories in their order of importance; that is to say, beginning with the daruriyyah and ending with the tahsiniyyah.

The three levels of the pyramid of mașlahah are not mutually exclusive in the sense that all levels are inter-related and mutually dependent. The arrows pointing upwards and downwards along the pyramid of mașlahah reveal the flexibility and mechanism of change in the decision making in the sense that any element which comprises one level of mașlahah may be elevated upward or pushed downward depending on the different circumstances concerning the public at large. However, it should be noted that the flexibility posed by the principles of mașlahah is confined within the framework of the sharì $a h$ but not vice versa. ${ }^{37}$

This reflects the dynamism of the pyramid of mașlahah in assisting decisionmaking processes within different contexts, time and space. ${ }^{38}$ If, for instance the circumstances change, inviting firms to respond and consequently reconsider their roles within society, this will necessitate them to re-align all their business institutions (such as mission, vision, policy deployment, decision-making, reporting, corporate affairs, etc.) to the new mașlahah so long as it does not contradict the principles outlined by the sharì'ah. 
To further enlighten our argument on the pyramid of mașlahah, particularly on how it can be applied to Islamic financial endeavours, we shall analyse the different levels of decision-making processes based on each principle of mașlahah.

At the first level, within the scope of the essentials, managers are expected to strive for the preservation and protection of the essential needs (religion, life, intellect, posterity and property) of their stakeholders and public interests in general. For example, banks must always confine their business operations to those that safeguard the values of religion, life, intellect, posterity and property. Accordingly, Islamic banks have a religious, moral and social responsibility to avoid engaging themselves to any business activities, although there may be higher profits, which may cause disruption and chaos to society. ${ }^{39}$ Examples include business activities which can endanger the lives and disruption of people's intellect as a result of environmental degradation, and the manufacturing of illicit drugs for public consumption.

As soon as the scope within the essentials has been fulfilled, the corporations may strive for the second level, the complementary (häjiyyah) which is deemed beneficial to remove difficulties, even though it may not pose a threat to the very survival of normal order. ${ }^{40}$ For example Islamic banks that have fulfilled their essentials level should further extend their responsibilities. In this instance, the essential needs of employees such as fair pay and a safe workplace can be further extended to include continuous training and enhancing human quality programmes. The latter is not really essential in the sense that if managers neglect this kind of commitment, it will not pose severe harm to the employees. However, if the managers assume such a responsibility it is a fulfilment of the complementary interest that will advance the intellectual well-being (knowledge and skills) of the workers. In some cases, such effort can sometimes be considered as the essentials (mașlahah darüriyyah). For example, Islamic banking institutions need to provide adequate sharì $a h$ training to their employees concerning the Islamic financial instruments offered, so as to protect the interest of faith.

The top level in the pyramid of mașlahah is the principle of embellishments (tahsiniyyah). Within the ambit of the embellishments, the Islamic firms are expected to discharge their social responsibilities by engaging in activities or programmes that may lead to improvements and attainments of perfections of public life conditions. Involving in charity or giving donations to the poor and needy; offering interest-free loans, providing scholarships to the less fortunate students and providing sufficient, correct and clear information or advertisement regarding products offered to customers are some of the examples of Islamic banking commitment with respect to achieving the embellishments for society.

On the whole, the pyramid of mașlahah implies the need for Islamic financial institutions to engage and manage their businesses and activities according to 
priorities. These priorities evolved from a deep understanding of the objectives of the shari 'ah such that preservation of interests (mașlahah) is dealt with according to the different levels of importance and severity of consequences. For example, one must not focus on attaining embellishments while jeopardising the essentials. Similarly, one must not be obsessed with the attainment of benefits to the extent of creating harm or inflicting injury to others. The discussion of the harm prevention principle, which is pertinent to our discussion of implications of mașlahah to Islamic Finance, is further elaborated in the following section.

\section{The Principle of Harm Prevention in Islam}

The concept of mașlahah entails the understanding of the Islamic principle of harm prevention. Essentially, the principle states that while engaging in economic and business activities, a firm is prohibited from inflicting injury or causing grief to others. ${ }^{41}$ Generally, there are two major shari ${ }^{-} a h$ axioms imbued in the principle of harm prevention. One is the removal of hardship ( $r a f^{\prime \prime}$ al-haraj) and the other is prevention of harm (daf' al-darar). This concept occupies a central position in the framework of protection of social interest as enshrined in the principles of mașlahah, particularly in averting social harm. As such, a discussion of application of maqāșid to Islamic finance will be futile if such an important framework is undermined. ${ }^{42}$

This principle is based on an authentic hadìth narrated by Ibn Mājah and al-Dāruquțnī and others on the authority of Sa 'd b. Mālik al-Khudrī, who mentioned that the Messenger of Allah said: "There should be neither harming nor reciprocating harm" (Aḥmad b. Hanbal, Musnad, and Ibn Mājah, Sunan). Islamic scholars broadly classify harm or damage into two types: the first type is the harm or damage which occurs as a result of a deliberate action by a person upon parties or entities (e.g. environment). The second type is an action by a person with a solemn intention and permissible by the shari ${ }^{-} a h$; albeit in good faith, his action may directly or indirectly cause harm to other parties. While the former is strictly prohibited or haräm, the latter has to be examined in varying degrees and in various contexts to determine whether the action is permissible or otherwise. ${ }^{43}$

The study on the principle of harm prevention together with the concept of mașlahah has been a subject of wide discussion in the field of Islamic jurisprudence. A number of Islamic legal maxims were derived from this. For the purpose of this study, we simplify the discussion by providing a summary of Islamic maxims which derived from the concept of harm prevention. Table 1 summarises some of the most important Islamic legal maxims which are relevant and significant to our discussion on Islamic financial operation. Examples of their application to various Islamic finance operational related issues are also provided in the corresponding column to further illuminate our understanding of the maxims. 
Table 1 The Framework of Harm Prevention in Islam

\section{Islamic Maxim Description}

Harm is repelled Any potential harm to the society as far as possible.

Harm is put to an end.

No injury to be inflicted when lifting an injury.
In an attempt to remove harm or damage, it must not invoke another type of harm either in the same degree of harm or worse.
Severe damage is avoided by $a$ lighter damage.

To repel a public harm a private damage is preferred.

If harm or damage is unavoidable, the strategy is to choose a lighter damage. Another similar maxim is that the smaller of two harms is chosen.

One has to succumb to the damage which is private in nature in order to prevent social harm. In other words, a firm's operation should be biased in favour of society if two harmful acts are conflicting.

The repealing of If there is a conflict between harm harm is preferred and benefit, it is obligatory to repeal to the attainment or lift the harm first even if by so of benefits. doing it will remove the benefits. This is because harm can easily spread and cause severe damage, and hence priority ought to be given to the aversion of harm over attaining benefits.

\section{Examples of Application}

Islamic banks must not become involved in any activities that may in the longrun cause harm to society. For example, becoming involved in speculative trading activities which are not linked to the real economic activities such as the derivatives market.

If an Islamic bank identifies any sharī $a h$ violation in its activities, immediate action must be taken to rectify the transaction. Corrective measures must be put in place to ensure such an event may not recur in future.

In managing risk banks must not use conventional risk management tools which can invoke higher risk such as using derivatives or securitisation techniques like Credit-Default Swaps (CDS) and Mortgage-Backed Securities (MBS), which are proven to have detrimental effects on society in the long-run.

In the event where an Islamic bank has no other option except to use a controversial contract like tawarruq in managing its liquidity, it may do so because the damage of a collapsed bank due to liquidity crisis is more severe and can be disastrous to the whole financial system.

Avoiding of financing companies that manufacture illicit drugs or activities detrimental to public consumption is deemed necessary even at the expense of undermining individual profits.

A debt-based instrument like murābahah, given its legal and valid contract from the shari 'ah viewpoint, its extensive use accentuates inequality and exposes one to a wide-array of risk as it redistributes wealth in favour of suppliers of capital, irrespective of actual productivity of the finance supplied. Hence, it should be minimised and eventually averted. 


\section{Conclusion and Recommendations}

This article offers instructive discussion on the framework of maqāssid al-sharī'ah and its implication to the contemporary discourse on the shari ' $a h$-based finance. It has been made explicit in our discussion that

- Islamic finance as an institution grounded on the ethical and moral framework of Islamic law assumes a distinctive role in the society.

Furthermore, the framework of maqāṣid al-sharī'ah also implies that

- Islamic financial institutions' characteristics are shaped by the higher objectives of Islamic law emphasising overall social and economic good and not infectious greed and individualism.

Thus Islamic finance is much more than just refraining from charging interest and conforming to the legal technicalities and requirements on offering Islamic financial products. It is a holistic system which aims at contributing to the fulfilment of the socio-economic objectives and the creation of a just society. In the process of conducting business, Islamic financial institutions seek to bring about a lasting balance between earning and spending in order to achieve betterment for the whole community. This has been manifested as a higher objective of Islamic finance which is deeply inscribed in the maqāssid al-sharì $a h$. The message of Islamic finance is therefore very clear in that:

- Earning profits is commendable as long as it conforms to the principles of fairness and justice, as deeply inscribed in the $\operatorname{sharī~}^{\prime} a h$.

- Furthermore, Islamic guidance enshrined by its principle of justice brings about a balance between the rights of individuals and their duties and responsibilities towards others, and between self-interest and altruistic values.

With respect to managing diverse expectations and interests, the shari 'ah provides a framework for managers to resolve problems arising from the potential conflicting responsibilities towards the various stakeholders. In particular, the pyramid of mașlahah, together with the concept of harm prevention, which we have previously described, serve as a viable and effective model to devise a decision framework for making any trade-offs between the interests of various stakeholders. Therefore, both the pyramid of mașlahah and the harm prevention principle can contribute towards the establishment of guidelines for decision making in managing Islamic financial institutions. They also serve as viable models to devise principles for 
making trade-offs between the interests of diverse stakeholders. The framework also allows the managers to weigh and balance the interests at stake so that the various business objectives can be realised without causing harm or inflicting injury to any party.

\section{Notes}

1. This has been stated in the Qur'ān and the Sunnah and endorsed by Muslim scholars. See, for example, 'Izz al-Dīn 'Abd al-Salām, Qawā'id al-ahkeām fì masāliḥ al-anām, ed. 'Abd al-Lațīf 'Abd al-Raḥmān (Beirut: Dār al-Kutub al- 'Ilmiyyah, 1999), 1:3-8; Ibn Qayyim al-Jawziyyah, I' lām al-muwaqqi īn 'an rabb al- 'ālamīn, ed. Țaha 'Abd al-Ra ūf Sa 'd (Beirut: Dār al-J̄̄l, 1973), 3:3; Muḥammad al-Ṭāhir Ibn 'Āshūr, Maqāșid al-sharī'at al-islāmiyyah (Amman: Dār al-Nafā' is, 2001), 274 and 299; 'Abd al-Maj̄̄id al-Najjār, Maqāṣid al-sharī'ah bi-ab 'ād jadīdah (Beirut: Dār al-Gharb al-Islāmī, 2006).

2. Abū Ḥāmid al-Ghazālī, al-Mustașfā min 'ilm al-uṣūl (Cairo: al-Maktabah al-Tijāriyyah, 1937), 1:139-40; see also Abū Isḥāq Ibrāhīm b. Mūsā al-Shāțibī, al-Muwāafaqāt fí ușūl al-sharī'ah, ed. 'Abd-Allāh Darrāz, 4 vols (Beirut: Dār al-Ma rifah, 1975, 2nd ed.), 1:38 and 3:46-7.

3. Imran Ahsan Khan Nyazee, Theories of the Islamic Law: The Methodology of Ijtihad (Kuala Lumpur: The Other Press, 2002), 235.

4. Muḥammad Țāhir Ibn 'Āshūr, Treatise on Maqāṣid al-Sharī'ah, tr. and annot. Muhammad El-Tahir Al-Misawi (London and Washington: International Institute of Islamic Thought, 2006), 87.

5. These attributes correspond to Qur'ān 21:107 and 10:57.

6. A. Al-Raysuni, Imam Al-Shatibi's Theory of the Higher Objectives and Intents of Islamic Law (London and Washington: International Institute of Islamic Thought, 2005).

7. Many Islamic legal scholars advocated the principle of public welfare (maslahah) and the objectives of the sharì'ah (maqāṣid) in Islamic jurisprudence (fiqh), among them al-Juwaynī (d. 1085), al-Ghazālī (d. 1111), al-Rāzī (d. 1209), al-Āmid̄̄ (d. 1233), al-Salmī (d. 1261), al-Qarāfī (d. 1285), Ibn Taimiyyah (d. 1327), al-Shāțibī (d. 1388), Ibn al-Qayyim al Jawziyyah. See D. Abdel Kader, "Modernity, the Principles of Public Welfare (Mașlahah) and the End Goals of Shari'a (Maqāșid) in Muslim Legal Thought", Islam and Christian-Muslim Relations 14, no. 2 (2003), 163-74.

8. The plural of the Arabic word mașlahah is mașälih which means welfare, interest or benefit. Literally, mașlahah is defined as seeking the benefit and repelling harm. The words mașlahah and manfa 'ah are treated as synonyms. Manfa' $a h$ (benefit or utility), however, is not a technical meaning of mașlahah. What Muslim jurists mean by mașlahah is the seeking of benefit and the repelling of harm as directed by the Lawgiver. Refer to Imran Ahsan Khan Nyazee, Islamic Jurispudence (Usul al-Fiqh) (Islamabad: Islamic Research Institute Press, 2000).

9. Refer to Nyazee, Islamic Jurispudence.

10. Mohammad Hashim Kamali, "Maqasid al-Shari 'ah: The Objectives of Islamic Law", Islamic Studies Occasional Papers 33 (Islamabad: Islamic Research Institute, International Islamic University, 1999).

11. Ibn Qayyim al-Jawziyyah, I ' lām.

12. Cited by Ibn 'Āshūr, Treatise, 130 .

13. Muhammad b. Idrīs al-Shāfi 'ī, Al-Shāfi î̀s Risāla, tr. Majid Khadduri (Cambridge: Islamic Texts Society, 2003, repr.), 66.

14. Ibn 'Āshūr, Treatise, 67.

15. Mohammad Hashim Kamali, "Sources, Nature and Objectives of Shari'ah", Islamic Quarterly 33 (1989), 215-35.

16. See al-Shāṭib̄i, al-Muwāfaqāt, 2:266, Ibn 'Āshūr, Treatise, 142-150, and al-Najjār, Maqāṣid al-sharī'ah, 207. 
17. For further discussion of the given examples, refer to Nyazee's, Theories and his Islamic Jurispudence, and furthermore to M. Mumisa, Islamic Law: Theory and Interpretation (Beltsville MD: Amana Publications, 2002) and M.A. Zuhrah, Ușūl al-fiqh (Beirut: Dār al-Fikr al- 'Arabī, 1958).

18. al-Shāțib̄i, al-Muwāfaqāt, 2:267; Ibn 'Āshūr, Treatise, 120-1.

19. Ibn 'Āshūr, Treatise, 225.

20. A.W. Dusuki and A. Abozaid, "A Critical Appraisal on the Challenges of Realising Maqasid al-Shari 'ah in Islamic Banking and Finance", IIUM Journal of Economics and Management 15, no. 2 (2007), 143-65.

21. See al-Najjār, Maqāṣid al-sharī'ah, 83.

22. Mughärasah is a kind of land tenure or contract in which the landlord gives his barren land to someone to plant fruit trees in it; see Ibn 'Āshūr, Treatise.

23. Abū 'Īsā Muḥammad b. 'Īsā al-Tirmidhī, Sunan, “Aḥkām” (Beirut: Dār Ibn Ḥazm, 2002) ḥadīth no. 1,352, 3:634; 'Alī b. 'Umar al-Dāraquțn̄̄, Sunan (Beirut: Maktabat al-Jīl, 1986), 2:27.

24. Ibn 'Āshūr, Treatise.

25. Aḥmad b. Ḥanbal, Musnad (Beirut: Mu'assasat al-Risālah, 1999, 2nd ed.), 5:72; al-Dāraquṭn̄̄, Sunan, 3:26; Abū Aḥmad b. al-Ḥusayn b. 'Alī al-Bayhaq̄ī, al-Sunan al-kubrā (Beirut: Dār al-Fikr al- 'Arabī, n.d.), 6:100 and 8:182.

26. Ibn 'Āshūr, Treatise.

27. Ibid.

28. Ibid.

29. According to Wahbah al-Zuhaylī, al-Fiqh al-islāmī wa adillatuhu (Beirut: Dār al-Fikr, 2004), 1:142, one $s \bar{a}^{\prime}$ (a measure of capacity) is equal to about 2.75 litres; see, however, Christoph Marcinkowski, Measures and Weights in the Islamic World: An English Translation of Professor Walther Hinz's Handbook 'Islamische Maße und Gewichte', with a foreword by Professor Clifford Edmund Bosworth, FBA (Kuala Lumpur: ISTAC, 2003), 74-5.

30. Muḥammad b. Ismā̄îl al-Bukhārī, Șahīḥ al-Bukhārī (Beirut: Dār al-Ma rifah, 1961), hadīth no. 2,089 .

31. Z. Iqbal and A. Mirakhor, "Stakeholders Model of Governance in Islamic Economic System", paper presented at the 'Fifth International Conference on Islamic Economics and Finance: Sustainable Development and Islamic Finance in Muslim Countries', Manama, Bahrain, 2003.

32. M.U. Chapra, Islam and the Economic Challenge (Leicester UK: The Islamic Foundation, 1992).

33. A.W. Dusuki, "Understanding the Objectives of Islamic Banking: A Survey of Stakeholders' Perspectives", International Journal of Islamic and Middle Eastern Finance and Management 1, no. 2 (2008), 132-48.

34. Ibid.

35. The pyramid of mașlahah looks similar to but not necessarily the same as Abraham Maslow's (Toward a Psychology of Being (New York: Van Nostrand Reinhold, 1968)) hierarchy of needs. He established the theory based on the psychological, safety, love, esteem and self-actualisation needs of man. While the latter is based on naturalistic and materialistic perspectives to life, the former reaffirms the integralistic spiritual view of the universe to provide a better philosophical framework as an alternative for contemporary man's interaction with nature and his fellow men. S.H. Azmi ("Traditional Islamic Social Welfare: Its Meaning, History and Contemporary Relevance", Islamic Quarterly 35, no. 3-4 (1991), 165-80) asserts that Maslow's hierarchy of needs could not be applied totally in the 'Islamic need-set' as his hierarchy does not really deal with the "spiritual" needs. Instead he talks of 'self-actualisation' and puts that at a higher (and hence less basic) level of needs. K. Ahmad ("Islamic Ethics in a Changing Environment for Managers", in: K. Ahmad and A.M. Sadeq (eds), Ethics in Business and Management: Islamic and Mainstream Approaches (London: ASEAN Academic Press, 2002), 97-109) further reaffirms that Islamic understanding of upward mobility in an organisation is more comprehensive than the simple fulfilment as described by Abraham Maslow's hierarchy of needs. 
36. See detailed discussion in the following works by Mohammad Hashim Kamali: Principles of Islamic Jurispudence (Petaling Jaya, Selangor [Malaysia]: Pelanduk Publications, 1989); "Sources, Nature and Objectives of Shari'ah, Islamic Quarterly 33 (1989), 215-36; "Fundamental Rights of the Individual: An Analysis of Haqq (Right) in Islamic Law", Islamic Journal of Social Sciences 10, no. 3 (1993), 340-66; "Maqasid al-Shari 'ah"; and also in Zuhrah, Ușül al-fiqh; M. Mumisa, Islamic Law. Mumisa, Islamic Law; Imran Ahsan Khan Nyazee, Islamic Jurispudence (Usul al-Fiqh) (Islamabad: Islamic Research Institute Press, 2000); Nyazee, Theories.

37. Mumisa, Islamic Law.

38. Contemporary Islamic jurists like Ḥusayn Ḥamīd Ḥasan, Muhammad Sa īed Ramaḍān al-Būṭ̂n and Muștafă Zayd (as quoted in Mumisa, Islamic Law) all affirm the dynamism of mașlahah or public interest in Islamic figh, but it has to be carefully used in shaping the contemporary challenges in the modern world today. The touchstone to judge the validity of mașlahah is the Qur'ann and the Sunnah. Al-Būṭī in his book Dawābiṭ al-mașlahah fì al-sharì ah al-islāmiyyah (Cairo: Mu'assasat al-Risālah, 1982), cautions that mașlahah must not be used at random. He maintains that the effective way to preserve the shari' $a h$ in its ideal form is to determine mașlahah by the needs recognised in the shari $\bar{\imath}^{\prime} a h$, otherwise it will be exposed to extraneous factors which are against the spirit of the Qur'ān and the Sunnah.

39. The corresponding qur'ānic verse to support this is 28:77.

40. Kamali, "Maqasid al-Shari 'ah".

41. M.A.A. Sarker, "Islamic Business Contracts, Agency Problem and The Theory of the Islamic Firm", International Journal of Islamic Financial Services 1, no. 2 (September 1999), 12-28, also available online at http://eco.isu.ac.ir/edu/dlc/2rd/02/instructor/art2.pdf (accessed on 5 October 2010); M.A. Zuhrah, Ușūl al-fiqh (Beirut: Dār al-Fikr al-'Arabī, 1958).

42. According to M. Al-Bugha and M. Misto, A Discussion on An-Nawawi's 40 Hadith (Kuala Lumpur: Prospecta Printers, 1998), in quoting al-Suyūțī (d. 1505), based on his book al-Ashbāh wa 'l-nazā 'ir, this hadith is very significant as it embodies the fundamental principles and maxims of Islamic jurisprudence. Among the figh arguments deriving from this hadith is: If someone has caused damage to another party's property, it is not permissible for the affected party to retaliate by damaging the property of the person. This is because such action is deemed to aggravate the damages without any benefits in return, hence it is harmful. The alternative is paying compensation to the same value of the damaged property so as to avoid further harm to the property of the owner. See also Zuhrah, Ușül al-fiqh.

43. Al-Bugha and Misto, A Discussion; Zuhrah, Ușūl al-fiqh. 